\title{
The Usability of Scotch Pine (Pinus sylvestris) as a Biomonitor for Traffic-Originated Heavy Metal Concentrations in Turkey
}

\author{
Burak Aricak ${ }^{1}$, Mehmet Cetin ${ }^{2 *}$, Ramazan Erdem ${ }^{3}$, Hakan Sevik ${ }^{4}$, Hasret Cometen \\ ${ }^{1}$ Kastamonu University, Faculty of Forestry, Department of Forest Engineering, Kastamonu, Turkey \\ ${ }^{2}$ Kastamonu University, Faculty of Engineering and Architecture, Department of Landscape Architecture, \\ Kastamonu, Turkey \\ ${ }^{3}$ Kastamonu University, Arac Rafet Vergili Vocational School, Department of Forestry, Programs of Forestry \\ and Forestry Products, Kastamonu, Turkey \\ ${ }^{4}$ Kastamonu University, Faculty of Engineering and Architecture, Department of Environmental Engineering, \\ Kastamonu, Turkey \\ ${ }^{5}$ Kastamonu University, Institute of Science, Programs of Forest Engineering, Kastamonu, Turkey
}

Received: 28 December 2018

Accepted: 8 May 2019

\begin{abstract}
Heavy metals are one of the most infamous air pollutants. They do not deteriorate easily in nature and they tend to bioaccumulate in nature. Because of their significance in terms of potential damage to human and environmental wellbeing, the monitoring of heavy metal pollution and identifying risk-prone regions is of great importance. Bioindicators are the most important determinants of the change in the concentration of heavy metals in the atmosphere. While plants play the biggest and most important role in reducing pollution in all of its types, they are also the ideal bioindicators. However, some plant species are better equipped to detect heavy metal accumulation than others. This study aims to determine the usability potential of Scotch pine (Pinus sylvestris) in monitoring traffic-based heavy metal concentrations. For this purpose, samples of Scotch pine individuals were collected from one of the busiest highways in Turkey (along the Ankara-Istanbul route) from refuges at roadsides and at distances of $3 \mathrm{~m}, 10 \mathrm{~m}, 30 \mathrm{~m}, 50 \mathrm{~m}$, and $100 \mathrm{~m}$ from the roadside. Some of the branches and needles of the samples were also subjected to washing processes and the changes of $\mathrm{Ni}, \mathrm{Cr}$ and $\mathrm{Zn}$ concentrations were determined for these samples. The change of $\mathrm{Ni}, \mathrm{Cr}$ and $\mathrm{Zn}$ concentrations depending on the distance to the road, washing conditions and organelle were evaluated separately. We determined that Scotch pine is a good biomonitor - especially for monitoring changes in $\mathrm{Cr}$ concentrations.
\end{abstract}

Keywords: heavy metal, biomonitor, traffic, Scotch pine, Pinus sylvestris

*e-mail: mcetin@kastamonu.edu.tr 


\section{Introduction}

The population of the world has increased more than ever in the last 150 years, and this increase combined with the rural-urban emigration has caused an extreme population density in cities [1-3]. It is estimated that $60-90 \%$ of the world's population will live in urban areas by 2030 [4].

Increasing population in urban centers, developing industry and technological developments have caused environmental pollution, which has become one of the biggest problems of the modern world [5-10]. It is stated that approximately 6.5 million people die every year due to air pollution. It has been reported that even in Turkey - which is considered one of the countries with the least amount of air pollution - 29,000 people died of air pollution-related causes in 2016 [11].

Heavy metals are one of the main culprits for causing air pollution. Although micronutrients such as $\mathrm{Mn}, \mathrm{Zn}$, $\mathrm{Cr}, \mathrm{Cu}, \mathrm{Fe}$, and $\mathrm{Ni}$ are necessary for living organisms, including plants, they can cause harmful effects at high levels. Metals such as $\mathrm{Hg}, \mathrm{Cd}, \mathrm{As}$ and $\mathrm{Pb}$ have serious toxic impacts on organisms - even at low levels [12-14]. In addition, heavy metals do not deteriorate easily in nature and tend to bioaccumulate [4, 10, 13].

It is known that vehicles have a significant share in increasing the heavy metal pollution. The biggest sources of heavy metal emissions are industrial activities and traffic $[12,15]$. It has been determined in many studies that there is a significant relationship between traffic density and heavy metal pollution. It has been determined that there is an exact correlation between the amount of some heavy metal concentrations in plant leaves and the distance of the plant to the traffic source $[4,13,16]$.

Monitoring heavy metal pollution and identifying risk-prone regions is of great importance. Plants accumulate some of the heavy metals in their bodies via soil or air; and by determining the level of this accumulation, data on heavy metal pollution in soil or air can be obtained $[4,12]$. Therefore, the leaves of large plants [16-19], body shells [20], woods [21] and fruits [22] are used as biomonitors.

However, different heavy metals can accumulate at different levels in organelles. Therefore, it is very important to determine the level of each heavy metal accumulation in different organelles, and to use these plants and organelles as biomonitors in order to obtain more reliable results from research. This study aimed to determine the change of some heavy metals in Pinus sylvestris depending on the plant organelle and the distance from the main road where the traffic is heavy.

\section{Materials and Methods}

Our study was carried out on samples collected from Scotch pine (Pinus sylvestris) trees on the highway between Kaynaşlı Disrict of Düzce and Bolu. The highway we chose is one of the busiest highways in Turkey. The samples were collected from the branches that were on the highway side of the trees. The Scotch pine individuals were selected on a specific direction on the highway between Kaynaşlı District of Düzce Province and Bolu Province from the refuge, roadside and at $3 \mathrm{~m}, 10 \mathrm{~m}, 30 \mathrm{~m}, 50 \mathrm{~m}$ and $100 \mathrm{~m}$ distances. The $50 \mathrm{~cm}$ length of the branch samples collected from the roadside parts of seven Scotch pines constitutes the materials of this study.

Samples brought to the laboratory were first divided into groups and some of the samples were washed. The samples were then separated into organelles and the bark of the wood was peeled. Washed needles, unwashed needles, washed bark, unwashed bark and wood samples were obtained. The samples were labeled and kept for 15 days until they got air dried. Air-dried samples were put in glass containers and dried in a drying oven at $50^{\circ} \mathrm{C}$ for one week.

The dried samples were pulverized by a steel blender in the laboratory. The pulverized samples were made to weigh $2 \mathrm{gr}$ each in $10 \mathrm{ml}$ concentrated $\mathrm{HNO}_{3}$ at room temperature for 1 day in the fume cupboard, and then boiled at $180^{\circ} \mathrm{C}$ for 1 hour. $20 \mathrm{ml}$ of distilled water were added to the prepared solutions and the solutions were filtered through a $45 \mu \mathrm{m}$ filter paper. The prepared solutions were numbered in order to prevent any mixups and prepared for analysis. In the solutions obtained from the filtrate, heavy metal analysis was performed with a GBC Integra XL ICSDS-270 ICP-OES device.

The obtained data were evaluated with the help of the SPSS package program, variance analysis was applied to the data and homogeneous groups were obtained by applying the Duncan test to the values having at least $95 \%$ confidence level differences statistically. The obtained data was simplified and tabulated and interpreted.

\section{Results and Discussion}

The change in Ni concentration due to organelle and distance to the traffic source was determined separately, and $F$ value and significance level obtained by variance analysis and homogeneous groups resulting from Duncan test are shown in Table 1.

As the result of variance analysis we determined that the change of $\mathrm{Ni}$ concentration was significant at 99.9\% confidence level for all factors. When the change of $\mathrm{Ni}$ concentration due to distance was examined, no significant change was observed in proportion to distance. For example, in the unwashed needle samples, the highest values were obtained in the samples that were collected from closest and furthest distance to the road. A similar situation was also noticeable in wood samples. The lowest values were obtained from the samples that were collected from the roadside and the longest distances. 
Table 1. Change of Ni concentration depending on organelle and distance from the road.

\begin{tabular}{|c|c|c|c|c|c|c|}
\hline \multirow{2}{*}{ Distance } & \multicolumn{2}{|c|}{ Needle } & \multicolumn{2}{|c|}{ Bark } & \multirow{2}{*}{ Wood } & \multirow{2}{*}{ F Value } \\
\hline & Washed & Unwashed & Washed & Unwashed & & \\
\hline 0 & $1015,2 \mathrm{Bd}$ & $2394,3 \mathrm{De}$ & $939,3 \mathrm{Ab}$ & $1597,0 \mathrm{Cd}$ & $1039,8 \mathrm{Bc}$ & $1737,837 * * *$ \\
\hline 1 & 345,7 Aabc & $674,3 \mathrm{Bb}$ & $924,7 \mathrm{Cb}$ & $1143,7 \mathrm{Dc}$ & $306,1 \mathrm{Aa}$ & $54,897 * * *$ \\
\hline 3 & $550,7 \mathrm{Ac}$ & $6793,6 \mathrm{Eg}$ & 4316,6 Dd & $973,6 \mathrm{Bb}$ & $1294,5 \mathrm{Cd}$ & $7462,612 * * *$ \\
\hline 10 & $220,7 \mathrm{Aab}$ & $197,6 \mathrm{Aa}$ & $1236,8 \mathrm{Cc}$ & $1695,0 \mathrm{De}$ & $1073,2 \mathrm{Bc}$ & $240,999 * * *$ \\
\hline 30 & $137,7 \mathrm{Aa}$ & $1647,8 \mathrm{Cd}$ & $599,5 \mathrm{Ba}$ & $745,2 \mathrm{Ba}$ & $2425,1 \mathrm{De}$ & $354,015 * * *$ \\
\hline 50 & $386,6 \mathrm{Abc}$ & $959,9 \mathrm{Bc}$ & $568,2 \mathrm{Aa}$ & $1706,0 \mathrm{Ce}$ & $4446,2 \mathrm{Df}$ & $559,206 * * *$ \\
\hline \multirow[t]{2}{*}{100} & 1871,4 De & $2394,3 \mathrm{Df}$ & $1128,0 \mathrm{Bc}$ & $1612,9 \mathrm{Cd}$ & $540,5 \mathrm{Ab}$ & $88,828^{* * *}$ \\
\hline & $78,558 * * *$ & $2968,363 * * *$ & $1102,578 * * *$ & $219,551 * * *$ & $614,329 * * *$ & \\
\hline
\end{tabular}

When the changes of the Ni concentration depending on organelles were examined, the difference between the washed and unwashed samples was noteworthy. Concentrations in washed samples in almost all samples on both needles and barks were lower than the concentrations in the unwashed samples. The organelle and distance-related changes of $\mathrm{Cr}$ concentrations in organelles were determined separately and mean values, $F$ value and significance level obtained as a result of analysis of variance and homogeneous groups as a result of Duncan test are given in Table 2.

We determined that the change of $\mathrm{Cr}$ concentration was significant at $99.9 \%$ confidence level for all factors. When the change of $\mathrm{Cr}$ concentration depending on distance was examined, it was seen that the amount of $\mathrm{Cr}$ concentration decreases in most of the samples as distance increases. When the values obtained from 50 and $100 \mathrm{~m}$ distances, which were the furthest distances, were examined it was seen that the majority of the data were in the first homogeneous group as a result of Duncan test.

When the change of $\mathrm{Cr}$ concentration depending on the organelle was examined, we noted that all the wood samples take place in the first homogenous group resulting from Duncan test. Therefore, the lowest values were obtained in wood samples. Moreover, the difference between wood and other organelles can be five times more in the samples taken from the same branch. It is also noteworthy that the values obtained from the bark were significantly higher than the values obtained from the needles.

The organelle and distance-related changes of $\mathrm{Zn}$ concentrations in organelles were determined separately and mean values, F value and significance level obtained as a result of analysis of variance and homogeneous groups as a result of Duncan test are given in Table 3.

As a result of the variance analysis, we determined that the change of $\mathrm{Zn}$ concentration depending on distance and organelle was significant at least at $95 \%$ confidence level for all factors. When the change of $\mathrm{Zn}$ concentration due to distance was examined, no significant change was observed in proportion to distance. From the needles, the lowest and highest values of washed samples were obtained at the nearest distance to the road, while the lowest values of unwashed samples were also obtained at the nearest distance to

Table 2. Change of $\mathrm{Cr}$ concentration depending on organelle and distance.

\begin{tabular}{|c|c|c|c|c|c|c|}
\hline \multirow{2}{*}{ Distance } & \multicolumn{2}{|c|}{ Needle } & \multicolumn{2}{c}{ Bark } & \multirow{2}{*}{ Wood } & \multirow{2}{*}{ F Value } \\
\cline { 2 - 6 } & Washed & Unwashed & Washed & Unwashed & & \\
\hline 0 & $419,3 \mathrm{Ac}$ & $508,9 \mathrm{Bc}$ & $1355,8 \mathrm{Dc}$ & $1443,7 \mathrm{Ce}$ & $414,2 \mathrm{Ab}$ & $449,106 * * *$ \\
\hline 1 & $323,3 \mathrm{Ab}$ & $536,8 \mathrm{Bc}$ & $1093,5 \mathrm{Cb}$ & $1165,0 \mathrm{Cd}$ & $244,0 \mathrm{Aa}$ & $103,365 * * *$ \\
\hline 3 & $438,2 \mathrm{Bc}$ & $541,0 \mathrm{Cc}$ & $677,1 \mathrm{Da}$ & $849,7 \mathrm{Ebc}$ & $265,2 \mathrm{Aa}$ & $69,784 * * *$ \\
\hline 10 & $282,0 \mathrm{Aab}$ & $418,2 \mathrm{Bb}$ & $1428,7 \mathrm{Dc}$ & $1210,0 \mathrm{Cd}$ & $285,7 \mathrm{Aa}$ & $757,441^{* * *}$ \\
\hline 30 & $278,3 \mathrm{Aab}$ & $275,8 \mathrm{Aa}$ & $717,6 \mathrm{Ba}$ & $701,9 \mathrm{Ba}$ & $284,3 \mathrm{Aa}$ & $46,041^{* * *}$ \\
\hline 50 & $241,4 \mathrm{Aa}$ & $585,6 \mathrm{Bc}$ & $705,0 \mathrm{BCa}$ & $769,1 \mathrm{Cab}$ & $365,7 \mathrm{Ab}$ & $28,742 * * *$ \\
\hline 100 & $274,9 \mathrm{Aab}$ & $395,7 \mathrm{Ab}$ & $585,5 \mathrm{Ba}$ & $932,5 \mathrm{Cc}$ & $274,7 \mathrm{Aa}$ & $49,678^{* * *}$ \\
\hline & $15,763 * * *$ & $13,235^{* * *}$ & $58,617 * * *$ & $34,260 * * *$ & $14,426 * * *$ & \\
\hline
\end{tabular}


Table 3. Change of $\mathrm{Zn}$ concentration depending on organelle and distance.

\begin{tabular}{|c|c|c|c|c|c|c|}
\hline \multirow{2}{*}{ Distance } & \multicolumn{2}{|c|}{ Needle } & \multicolumn{2}{|c|}{ Bark } & \multirow{2}{*}{ Wood } & \multirow{2}{*}{ F Value } \\
\hline & Washed & Unwashed & Washed & Unwashed & & \\
\hline 0 & $5,2 \mathrm{Aa}$ & $12,5 \mathrm{Ba}$ & $27,9 \mathrm{Db}$ & $42,6 \mathrm{Ef}$ & $13,3 \mathrm{Cc}$ & $83799,042 * * *$ \\
\hline 1 & $30,1 \mathrm{Bf}$ & $34,6 \mathrm{Cg}$ & $39,4 \mathrm{D} \mathrm{c}$ & $49,7 \mathrm{Eg}$ & $11,3 \mathrm{Ab}$ & $10150,938^{* * *}$ \\
\hline 3 & $22,5 \mathrm{Cc}$ & $22,5 \mathrm{Cc}$ & $19,2 \mathrm{Ba}$ & $25,1 \mathrm{Db}$ & 17,6 Af & $758,679 * * *$ \\
\hline 10 & $44,5 \mathrm{Eg}$ & $31,5 \mathrm{Be}$ & $39,5 \mathrm{Dc}$ & $35,9 \mathrm{Ce}$ & $13,6 \mathrm{Ad}$ & $11907,906 * * *$ \\
\hline 30 & $22,1 \mathrm{Db}$ & $23,9 \mathrm{Ed}$ & $18,4 \mathrm{Ca}$ & $17,2 \mathrm{Ba}$ & $16,1 \mathrm{Ae}$ & $1829,296^{* * *}$ \\
\hline 50 & $24,8 \mathrm{Cd}$ & $20,7 \mathrm{Bb}$ & $27,5 \mathrm{~Eb}$ & $25,6 \mathrm{Dc}$ & $8,7 \mathrm{Aa}$ & $6571,769 * * *$ \\
\hline 100 & $27,4 \mathrm{BCe}$ & $33,7 \mathrm{Cf}$ & $18,9 \mathrm{Aa}$ & $31,6 \mathrm{Cd}$ & $21,3 \mathrm{ABg}$ & $6,997 * *$ \\
\hline & $12146,249 * * *$ & $8886,543 * * *$ & $20,422 * * *$ & $15090,224 * * *$ & $3441,771 * * *$ & \\
\hline
\end{tabular}

the road. A similar situation is also noticeable in wood samples. The highest and lowest values of wood samples were obtained at the longest distances to the road.

As for the organelle-related change of $\mathrm{Zn}$ concentration, it is noteworthy that almost all of the wood samples were in the first homogenous group resulting from Duncan test. In addition, the concentration of $\mathrm{Zn}$ measured in most of the unwashed samples is higher than that measured in the washed samples.

$\mathrm{Ni}$, one of the elements examined within the scope of the study, is a carcinogenic element for mammals and other animals [12, 23]. Ni is used in coal, petroleum, steel, alloy production, galvanization and the electronics industry [24]. As a result of the study, it was determined that the concentration of $\mathrm{Ni}$ on unwashed samples was higher than the concentrations on washed samples in both needle and bark samples. This situation has also been revealed in various studies because heavy metals can hold on to various particles in the atmosphere after spreading $[11,12]$. Thus, the heavy metal concentrations on unwashed samples are measured higher compared to the washed samples due to the higher amount of particulate matter on these samples [25].

In this study and similar to former studies, it was determined that $\mathrm{Ni}$ concentration in plant organelles can reach up to $4446 \mathrm{ppb}$. Turkyilmaz et al. [19] stated that $\mathrm{Ni}$ concentrations in plant organelles were 4,381 $\mathrm{ppm}$ in the non-traffic areas, 5,840 ppm in areas with low dense traffic and up to $10,745 \mathrm{ppm}$ in areas with heavy traffic. Mossi [25] revealed that Ni concentrations in Buxus sempervirens reached up to $1639.1 \mathrm{ppb}$; while Turkyilmaz et al. [19] calculated 4,571 ppm in Tilia tomentosa, 4,746 ppm in Eleagnus angustifolia, 5,224 ppm in Ailanthus altissima and 13,413 ppm in Prunus cerasifera.

However, it has been revealed that the $\mathrm{Ni}$ concentration is lower in coniferous species. Mossi [25] stated that Ni concentration was 801,7 ppb in Juniperus sabina while Turkyilmaz et al. [13] calculated 225,3 ppb in Pinus sylvestris, $312.4 \mathrm{ppb}$ in Pinus nigra, $566 \mathrm{ppb}$ in Picea pungens and 1119.2 ppb in Abies bornmülleriana.
And as for the highest values of $\mathrm{Ni}$ concentrations they calculated $1801 \mathrm{ppb}$ in 3-year-old needles of Abies bornmülleriana. According to these results, it can be said that the value obtained in our study is quite high compared to the results obtained from coniferous species in previous studies.

$\mathrm{Cr}$, one of the heavy metals subjected to this study, is among the most toxic heavy metals in terms of potential toxicities and exposure to living organisms [12, 26]. Asthma attacks can be seen in people who show allergy to chromium, as well as nasal bleeding, nasal discharge, itching and upper respiratory tract perforations in case they take this heavy metal into their body through the air [24]. The dry matter in plants is also toxic to many tall plants at $100 \mathrm{mg} / \mathrm{kg}$ [24]. Non-essential metals such as $\mathrm{Cr}$ may enter the leaves of the plant through leaf transfer [27].

As a result of the study, we determined that the amount of $\mathrm{Cr}$ concentration in plants varies depending on the distance of plants to the traffic source. Therefore, the concentration of $\mathrm{Cr}$ increases in regions where traffic density increases. Similar results were obtained in many studies. Turkyilmaz et al. [19] indicated that the concentration of $\mathrm{Cr}$ increased up to $23,716 \mathrm{ppm}$ in the areas with heavy traffic while it was $16,595 \mathrm{ppm}$ in on-traffic areas. Sawidis et al., [20] stated that the $\mathrm{Cr}$ concentrations in the control group of Platanus orientalis leaves were calculated as $0,227 \mu \mathrm{g} / \mathrm{g}$ in Salzburg, $0,404 \mu \mathrm{g} / \mathrm{g}$ in Belgrade and 0,558 $\mu \mathrm{g} / \mathrm{g}$ in Thessaloniki, while reaching up to $0,388 \mu \mathrm{g} / \mathrm{g}$ in Salzburg, $0,472 \mu \mathrm{g} / \mathrm{g}$ in Belgrade and $0,621 \mu \mathrm{g} / \mathrm{g}$ in Thessaloniki in samples that were collected from contaminated regions. Similarly, they stated that the Cr concentration amount in control group of Pinus nigra leaves was calculated as $0,386 \mu \mathrm{g} / \mathrm{g}$ in Salzburg, 0,333 $\mu \mathrm{g} / \mathrm{g}$ in Belgrade and $0,621 \mu \mathrm{g} / \mathrm{g}$ in Thessaloniki; while it reached up to $0,423 \mu \mathrm{g} / \mathrm{g}$ in Salzburg, 0,576 $\mu \mathrm{g} / \mathrm{g}$ in Belgrade and $0,661 \mu \mathrm{g} / \mathrm{g}$ in Thessaloniki in samples that were collected from contaminated regions [28].

Within our study it has been determined that the amount of $\mathrm{Cr}$ concentration varies significantly 
depending on plant organelle, and the amount of $\mathrm{Cr}$ concentration in wood samples were very low so that even in the samples that were collected from the same branch, the difference between the amount of $\mathrm{Cr}$ concentrations of other organelles were five times more than the amount calculated in wood samples. Apart from this, the values obtained from the bark samples were noticeably higher that the values obtained from the needle samples.

$\mathrm{Cr}$ is reported as one of the elements of which the concentration amounts in plants differ most depending on species and organelle [25]. Turkyilmaz et al. [21] reported that the difference between the amount of $\mathrm{Cr}$ concentration in wood and bark is almost 9 times greater. Mossi (2018) revealed that the $\mathrm{Cr}$ concentration calculated in leaves was approximately 1,44 times more than the amount calculated in branches. $\mathrm{Cr}$ concentration was determined to rise up to $1443 \mathrm{ppb}$ in unwashed bark samples. In the study of Mossi [25], while $\mathrm{Cr}$ concentration in Eonymus japonica was calculated as $846.2 \mathrm{ppb}$; it was found to increase up to $2330.9 \mathrm{ppb}$ in Juniperus sabina.

$\mathrm{Zn}$, another heavy metal subjected to this study, is an essential element for humans, animals and plants [29]. $\mathrm{Zn}$ is involved in protein and carbohydrate synthesis in plants. In addition, it is effective on biological membrane stability as well as enzyme activation, photosynthesis and respiratory activities. Therefore, it directly affects the quantity and quality of the plant product [23].

Although $\mathrm{Zn}$ is involved in many vital functions in human and animal organisms, it is toxic in high amounts [25]. $\mathrm{Zn}$ is used in many fields such as cosmetics, paints, inks, copy papers, linoleum, rubber, and the metal industry in metal coatings and alloys in industry. It reaches the soil through wastewater released from intensive industrial areas, and through acid rain and sewage water. The observed $\mathrm{Zn}$ toxicities usually start after $400 \mathrm{ppm}$. Root growth slows down, roots get thinner, young leaves get curled, chlorosis appears, cell growth and elongation get precluded, cell organelles get degraded and the synthesis of chlorophyll decreases [24].

According to the data obtained from the study, $\mathrm{Zn}$ concentration was determined to be lower in wood samples than in other organelles. Similar results have also been revealed in different studies. Turkyilmaz et al. [21] reported that the average $\mathrm{Zn}$ concentration measured in wood samples of Acer platanoides was $3.59 \mathrm{ppb}$, while this amount increased to $14.79 \mathrm{ppb}$ in bark samples. Similar results were also obtained in different studies [4, 13, 14, 19, 21].

We also determined that the concentration of $\mathrm{Zn}$ measured in unwashed samples was higher than the amount measured in washed samples. Numerous studies have been conducted on the change of $\mathrm{Zn}$ concentration depending on plant organelle $[19,30]$, traffic density [3133], location [34-36] and plant species [4, 13].

In this study, we determined that the amount of $\mathrm{Zn}$ concentration in chosen plants increased up to
49.7 ppm. Similar values were obtained by previous studies. Mossi [25] states that the concentration of $\mathrm{Zn}$ reached up to $25,13 \mathrm{ppm}$ in areas with heavy traffic. Similarly, Demirayak et al. [37] stated that they calculated $\mathrm{Zn}$ concentration in L.vulgare leaves at a level of $70 \mathrm{ppm}$ in Samsun; Tanushree et al. [38] reported $83 \mathrm{mg} \mathrm{kg}^{-1}$ of $\mathrm{Zn}$ concentration

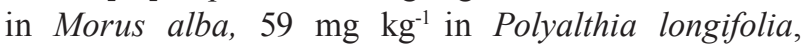
$49 \mathrm{mg} \mathrm{kg}-1$ in Ficus bengalensis, and $42 \mathrm{mg} \mathrm{kg}^{-1}$ in Alstonia scholaris in India. However, Aksoy and Şahin [39] reported the average amount of $\mathrm{Zn}$ concentration in unwashed leaf samples of $E$. angustifolia as $231,26{\mu g^{-1}}^{-1}$ industrial regions, 83,52 $\mu \mathrm{gg}^{-1}$ in roadside regions, $69,14 \mu \mathrm{gg}^{-1}$ in a city center, $38,16 \mu \mathrm{gg}^{-1}$ in suburbs and $22,08 \mu \mathrm{gg}^{-1}$ in rural areas. Serbula et al. [40] determined that the amount of $\mathrm{Zn}$ concentration could reach up to $192,7 \mathrm{mgkg}^{-1}$ in branches of Robinia pseudoacacia. Celik et al. [41] stated that they calculated the amount of $\mathrm{Zn}$ concentration in Robinia pseudoacacia L. samples that were collected from Denizli Province as 456,88 $\mu \mathrm{g} \mathrm{g}^{-1}$ in industrial regions, $456,88 \mu \mathrm{g} \mathrm{g}^{-1}$ in a city center, and $81,23 \mu \mathrm{g} \mathrm{g}^{-1}$ in suburbs.

Reducing environmental pollution has become an important agenda in today's urban life quality. Green areas, which are an important part of urban ecosystems, are important implementation tools because they reduce airborne pollution and thus increase quality of life. Various pollutants (industrial, domestic, traffic, etc.) exist in and around cities. Air pollution is quite high in urban roads, which are also open-green areas. The polluted gases in the air are 5-25 times and the dust concentration and particles are 10 times higher in urban areas than the surrounding rural areas [42, 43]. In developing cities of Turkey, while the number of vehicles involved into urban or suburban traffic is rising day by day, the traffic-related pollution has also started to increase [25] (Mossi, 2018). This negatively affects the quality of the environment and increases the importance of urban planting.

It has been determined in studies aimed at determining air pollution in cities that air pollution varies according to many factors such as traffic density, climate change, wind direction and precipitation $[2,44$, 45]. Therefore, the concentration of heavy metals in the air may vary depending on many parameters. In order to monitor this change and to effectively use plants in order to reduce heavy metal concentrations, studies on this subject are of great importance.

\section{Conclusions}

In the selection of the plants used in urban centers, visual qualities are generally prioritized and their functional uses are of secondary importance. However, plant species should be determined primarily by considering which plant species is more effective at performing the desired function. 
Scotch pine is an appropriate plant species to use in urban plantations for being quite resistant even to cold climate conditions as well as being evergreen. Also, being an evergreen coniferous and of low maintenance, requiring a plant with low needs of soil and water makes this species a valuable landscape plant. In addition to all these advantages this study revealed that this species is a good biomonitor of $\mathrm{Cr}$ pollution.

Currently, air pollution in city centers is one of the most important problems of cities. Therefore carrying on this type of research by dissemination and diversification is of great importance in order to determine the most effective species for the removal of heavy metals from the air. Beside determining appropriate species for biomonitoring, organelle and air conditioning-based studies must also be conducted in order to reveal the heavy metal accumulation depending on plant organelle and air conditions in future studies.

\section{Conflict of Interest}

The authors declare no conflict of interest.

\section{References}

1. ISINKARALAR O., ISINKARALAR K., EKIZLER A., ILKDOGAN C. Changes in the Amounts of $\mathrm{CO}_{2}$ and Particulate Matter in Kastamonu Province Depending on Weather Conditions and Locations, Journal of Chemical, Biological and Physical Sciences, 7 (3), 643, 2017.

2. CETIN M., SEVIK H., ISINKARALAR K. Changes in the Particulate Matter and $\mathrm{CO}_{2}$ Concentrations Based on the Time and Weather Conditions: The Case of Kastamonu. Oxid. Commun., 40 (1-II), 477, 2017.

3. ÇETIN N., MANSUROĞLU S., KALAYCI ÖNAÇ A. Xeriscaping Feasibility as an Urban Adaptation Method for Global Warming: A Case Study from Turkey. Pol. J. Environ. Stud., 27 (3), 1009, 2018.

4. TURKYILMAZ A., CETIN M., SEVIK H., ISINKARALAR K., SALEH E.A.A. Variation of heavy metal accumulation in certain landscaping plants due to traffic density. Environment, Development and Sustainability, 1-14, DOI: https://doi.org/10.1007/s10668018-0296-7, 2018.

5. GÜLGÜN B., GÜNEY M.A., AKTAŞ E., YAZICI K. Role of Landscape Architect in Interdisciplinary Planing of Sustainable Cities. Journal of Environmental Protection and Ecology 15 (4), 1877, 2014.

6. MUTLU E. The effects of lead-induced toxicity on metabolic biomarkers in common carp (Cyprinus carpio L.). Fresenius Environ Bull 25(5),1419-1427, 2016.

7. MUTLU E., DEMIR T., YANIK T., ANCA SUTAN N. Determination of environmentally relevant water quality parameters in Serefiye Dam-Turkey. Fresenius Environ Bull 25 (12), 5812, 2016.

8. KAYA E., AGCA M., ADIGUZEL F., CETIN M. Spatial data analysis with $\mathrm{R}$ programming for environment. Human and Ecological Risk Assessment: An International Journal. https://doi.org/10.1080/10807039.2018.1470896, 2018.

9. CETIN M., SEVIK H., CANTURK U., CAKIR C. Evaluation of the recreational potential of Kutahya urban forest. Fresenius Environmental Bulletin. 27 (5), 2629, 2018.

10. CETIN M., KALAYCI ONAC A., SEVIK H., SEN B. Temporal and regional change of some air pollution parameters in Bursa Air Quality, Atmosphere \& Health (Air Qual Atmos Health) (2018). DOI: https://doi. org/10.1007/s11869-018-00657-6, 2018.

11. SALEH, E.A.A. Determination of heavy metal accumulation in some landscape plants, Kastamonu University Institute of Science Department of Forest Engineering, Ph.D. Thesis, Kastamonu, Turkey, 2018.

12. SHAHID M., DUMAT C., KHALIDA S., SCHRECK E., XIONG T., NABEEL N. K. Foliar heavy metal uptake, toxicity and detoxification in plants: A comparison of foliar and root metal uptake. Journal of Hazardous Materials, 325, 36, 2017.

13. TURKYILMAZ A., SEVIK H., CETIN M. The use of perennial needles as bio-monitors for recently accumulated heavy metals. Landsc Ecol Eng 14 (1),115, https://doi. org/10.1007/s11355-017-0335-9, 2018.

14. TURKYILMAZ A., SEVIK H., ISINKARALAR K., CETIN M. Use of tree rings as a bioindicator to observe atmospheric heavy metal deposition, Environmental Science and Pollution Research, DOI: 10.1007/s11356-0183962-2, 2018.

15. MARTLEY E., GULSON B., PFEIFER H.R. Metal concentrations in soils around the. Australia, Sci. Toplam Environ. 325,113, 2004.

16. GRATANI L., CRESCENTE M.F., VARONE L. Longterm monitoring of metal pollution by urban trees. Atmospheric Environment, 42, 8273, 2008.

17. MONACI F., MONI F., LONCIOTTI E., GRECHI D., BARGAGLI R. Biomonitoring of airborne metals in urban envi-ronments: new tracers of vehicle emission, in place of lead. Environmental Pollution, 107, 321, 2000.

18. ANICIC M., SPASIC T., TOMASEVIC M., RAJSIC S., TASIC M. Trace elements accumulation and temporal trends in leaves of urban deciduous trees (Aesculus hippocastanum and Tilia ssp.). Ecological Indicators, 11, 824, 2011.

19. TURKYILMAZ A., SEVIK H., CETIN M., AHMAIDA SALEH E.A. Changes in heavy metal accumulation depending on traffic density in some landscape plants. Pol J Environ Stud 27 (5), 2277, https://doi. org/10.15244/ pjoes/78620, 2018.

20. SAWIDIS T., BREUSTE J., MITROVIC M., PAVLOVIC P., TSIGARIDAS K. Trees as bioindicator of heavy metal pollution in three European cities. Environmental Pollution, 159, 3560, 2011.

21. TURKYILMAZ A., SEVIK H., ISINKARALAR K., CETIN M. Using Acer platanoides annual rings to monitor the amount of heavy metals accumulated in air. Environ Monit Assess 190, 578. https://doi.org/ 10.1007/s10661-0186956-0, 2018

22. CETIN M., SEVIK H., YIGIT N. Climate type-related changes in the leaf micromorphological characters of certain landscape plants. Environ Monit Assess. 190, 404. https://doi.org/10.1007/s10661-018-6783-3, 2018.

23. OKCU M., TOZLU E., KUMLAY A.M., PEHLUVAN M. Effects of Heavy Metals on plants. Journal of Alınteri, 17, 14, 2009.

24. ASRI F.Ö., SÖNMEZ S. Effects of heavy metal toxicity on plant metabolism. Derim, Journal of Western Mediterranean Agricultural Institute, 23 (2), 36, 2006.

25. MOSSI M.M.M. Determination Of Heavy Metal Accumulation In Some Shrub Formed Landscape Plants, 
Kastamonu University Institute of Science Department of Forest Engineering, PhD Thesis, 2018.

26. SHAHID M., KHALID S., ABBAS G., SHAHID N., NADEEM M., SABIR M., ASLAM M., DUMAT C. Heavy metal stress and crop productivity, in: K.R. Hakeem (Ed.), Crop Production and Global Environmental Issues SE - 1, Springer International Publishing, 1, 2015.

27. LEVI E., DALSCHAERT X., WILMER J. Retention and absorption of foliar applied Cr. Plant Soil, 38, 683, 1973.

28. SAWIDIS T., BREUSTE J., MITROVIC M., PAVLOVIC P., TSIGARIDAS K. Trees as bioindicator of heavy metal pollution in three European cities. Environmental Pollution, 159, 3560, 2011.

29. PAK O. An Investigation of Some Heavy Metal Pollution Along the TEM Motorway Soils in Kirklareli, Namık Kemal University Graduate School of Natural and Applied Sciences Main Science Division of Soil Science and Plant Nutrition, MSc. Thesis, 2011.

30. SEVIK H., OZEL H. B., CETIN M., OZEL H.U., ERDEM $\mathrm{T}$. Determination of changes in heavy metal accumulation depending on plant species, plant organism, and traffic density in some landscape plants. Air Quality, Atmosphere \& Health, https://doi.org/10.1007/s11869-018-0641-x, 1, 2018.

31. LIU A., LIU L., LI D., GUAN Y. Characterizing heavy metal build-up on urban road surfaces: Implication for stormwater reuse. Science of the Total Environment, 515, 20, 2015.

32. HUBER M., WELKER A., HELMREICH B. Critical review of heavy metal pollution of traffic area runoff: Occurrence, influencing factors, and partitioning. Science of the Total Environment, 541, 895, 2016.

33. YANG P., GE J., YANG M. Identification of Heavy Metal Pollution Derived From Traffic in Roadside Soil Using Magnetic Susceptibility. Bulletin of environmental contamination and toxicology, 98 (6), 837, 2017.

34. ALSBOU E.M.E., AL-KHASHMAN O.A. Heavy metal concentrations in roadside soil and street dust from Petra region, Jordan. Environmental Monitoring and Assessment, 190 (1), 48, 2018.

35. QING X., YUTONG Z., SHENGGAO L. Assessment of heavy metal pollution and human health risk in urban soils of steel industrial city (Anshan), Liaoning, Northeast China. Ecotoxicology and environmental safety, 120, 377, 2015.

36. AHMED M. J. K., AHMARUZZAMAN M. A review on potential usage of industrial waste materials for binding heavy metal ions from aqueous solutions. Journal of Water Process Engineering, 10, 39, 2016.

37. DEMIRAYAK A., KUTBAY H.G., KILIC D., BILGIN A. HUSEYINOVA R. Heavy Metal Accumulation in Some Natural and Exotic Plants in Samsun City. Ecology, 20 (79), 1, 2011.

38. TANUSHREE B., CHAKRABORTY S,. BHUMIK F., PIYAL B. Heavy Metal concentrations in Street and Leaf Deposited Dust in Anand City, India, Research Journal of Chemical Sciences, 1 (5), 61, 2011.

39. AKSOY A., SAHIN U. Elaeagnus angustifolia L. as a biomonitor of heavy metal pollution. Turkish Journal of Botany, 23, 83, 1999.

40. SERBULA, M. S., MILJKOVIC, D.D., KOVACEVIC, M.R., ILIC, A.A. Assessment of airborne heavy metal pollution using plant parts and topsoil, Ecotoxicology and Environmental Safety, 76, 209, 2012.

41. CELIK A., KARTAL A.A., KASKA Y. Determining the heavy metal pollution in Denizli (Turkey) by using Robinia pseudo-acacia L. Environment International, 31, $105,2005$.

42. OZTURK S., BOZDOGAN E. The Contribution of Urban Road Trees on Improving The Air Quality in an Urban Area. Fresenius Environmental Bulletin, 24 (5), 1, 2015.

43. CETIN M., SEVIK H. Change of air quality in Kastamonu city in terms of particulate matter and $\mathrm{CO}_{2}$ amount. Oxidation Communications, 39 (4), 3394, 2016.

44. OZEL H. B., OZEL H. U., VAROL T. (2015) Using Leaves of Oriental Plane (Platanus orientalis L.) to Determine the Effects of Heavy Metal Pollution Caused by Vehicles. Pol. J. Environ. Stud. 24 (6), 2569, 2015.

45. CETIN M., SEVIK H., YIGIT N., OZEL H.B., ARICAK B., VAROL T. The variable of leaf micromorphogical characters on grown in distinct climate conditions in some landscape plants. Fresenius Environmental Bulletin, 27 (5), 3206, 2018. 